\title{
Reducing homicide through policy interventions: The case of gun control
}

\author{
R Matzopoulos, ${ }^{1,2} \mathrm{PhD} ;$ M Prinsloo, ${ }^{1} \mathrm{PhD} ;$ D Bradshaw, ${ }^{1,2} \mathrm{MSc}, \mathrm{DPhil} ; \mathrm{N}$ Abrahams, ${ }^{3} \mathrm{PhD}$ \\ ${ }^{1}$ Burden of Disease Research Unit, South African Medical Research Council, Tygerberg, Cape Town, South Africa \\ ${ }^{2}$ School of Public Health and Family Medicine, University of Cape Town, South Africa \\ ${ }^{3}$ Gender and Health Research Unit, South African Medical Research Council, Tygerberg, Cape Town, South Africa
}

Corresponding author: R Matzopoulos (richard.matzopoulos@uct.ac.za)

Injuries impose a fourth major disease burden on the South African population, which is driven in particular by the high incidence of interpersonal violence. There was a significant decline in mortality from interpersonal violence between 1997 and 2012 , and research conducted by South African Medical Research Council (SAMRC) researchers has ascribed much of this decline to a decrease in firearm homicide. In the present brief review, we summarise South African research on fatal and non-fatal firearm injuries, with a particular focus on research conducted by SAMRC intra- and extramural units between 1969 and 2019. More recent data suggest a lapse in firearm control that has led to an increase in homicide and that the fluctuating homicide rate is being influenced by adherence to firearm control policies.

S Afr Med J 2019;109(11 Suppl 1):63-68.https://doi.org/10.7196/SAMJ.2019.v109i11b.14256

The burden of disease in many countries is shifting towards noncommunicable diseases as communicable diseases are brought under control. This transition has been slower in Africa, and in many subSaharan African countries and, in South Africa (SA) in particular, the HIV/AIDS epidemic has imposed a third major disease burden. SA stands alone in suffering a fourth concurrent major disease burden due to injuries, which shows little sign of abating. Injury rates were $50 \%$ higher than the global average in $2009^{[1,2]}$ and the mortality profile was unusual, with intentional causes accounting for the greatest share, with homicide rates in particular far exceeding global averages. ${ }^{[2]}$ The South African Medical Research Council's (SAMRC's) National Burden of Disease study has shown that there has been a considerable decline in injury deaths between 1997 and 2012 from 153 to 98 per 100000 population. Closer inspection of the injury trends reveals that most of the decline has been attributable to a reduction in homicide. ${ }^{[3]}$ Research conducted by SAMRC researchers has ascribed much of this decline to a decrease in firearm homicide rates specifically rather than a decrease in violence per se. The decline in non-firearm homicide - a proxy for violence in society more broadly - has remained fairly constant. ${ }^{[4-6]}$

Not only have SAMRC researchers been at the forefront of documenting this declining homicide trend and the role of stricter firearm control in driving this decline, but the organisation and the corresponding legislation are also intertwined. The promulgation of the South African Medical Research Council Act (Act No. 19 of 1969) preceded by just a few months the Arms and Ammunition Act (AAA) - Act No. 75 of 1969. The latter Act underwent 20 amendments over a 30-year period before it was replaced by the Firearms Control Act (FCA) of 2000, which introduced more stringent eligibility and competency requirements for state and civilian firearm owners, and also included provisions for the prevention of gender-based violence. In the present brief review, we summarise SA research on fatal and nonfatal firearm injuries, with a particular focus on research conducted by SAMRC intra- and extramural units between 1969 and 2019.

We searched Pubmed and Scopus using 'guns' and 'firearms' and derivatives thereof as keywords, the SAMRC library catalogue, the reference lists of included articles and the authors' personal archives.
Two authors reviewed titles and sorted the studies according to three broad categories: (i) public health, which included studies describing the epidemiology (profile and aetiology) of firearm injuries and fatalities in the general population or selected sub-groups (e.g. children, women, etc); (ii) health systems, detailing case management implications of firearm injuries in the healthcare setting; and (iii) nature of injury, describing the clinical presentation and management of firearm injuries as they affect different regions of the body. For public health and selected health systems studies, we reviewed abstracts and full-text articles where available.

We provide summary data describing the scope and extent of the published research over these five decades (1969 - 2019) and, based on the public health and health systems studies, we present firearmrelated injury epidemiology alongside the prevailing political climate as it related to firearms in society and the health sciences research environment at the SAMRC and within SA more broadly.

\section{Summary of SA public health firearm research}

1969 - 1979 - the Arms and Ammunitions Act and the founding of the SAMRC

The AAA provided the underlying policy framework for the regulation of firearms throughout the apartheid years, including a perfunctory race-based application system. Unlike the FCA, the AAA did not require an extensive background check, nor a competency certificate to demonstrate the aspirant firearm owner's ability to handle a firearm safely and their understanding of the legislation. It imposed a limit of 12 guns that could be licensed to an individual, but no mechanism to ensure that they were still in the owner's possession, and there was no process for the renewal of licences.

There was a steady market for firearms with the militarisation of the apartheid state - white men were particularly familiar with firearms, having been subject to compulsory conscription from 1967, and the armament of the white civilian population was a natural progression of their military service. The most widely known incident involving firearms was indicative of the time. On 16 June 1976, police used live ammunition on protesting schoolchildren in 
Soweto during the youth uprising, which is still commemorated in SA as Youth Day - a national public holiday.

During the 1970s, the work of the SAMRC had a largely biological focus which did not include public health research or intersections with social health issues. We were unable to locate any firearm-related research within the SAMRC archives or among SA health science publications (Table 1).

The fractured state of the apartheid health system was reflected in the available mortality statistics, with the health and well-being of the majority black population devolved for the most part to underresourced Bantustan administrations. In Fig. 1 we provide firearm mortality data from the Department of Home Affairs, which shows a moderate increase in firearm deaths amongst coloured, Indian and white people for the period 1968 to 1990 . Mortality data for the black population were included only from 1980 and the vital registration system was unable to accommodate the large increase in deaths requiring processing and recording. Vital registration data became increasingly unreliable until overarching legislation was repealed and revised with the Births and Deaths Registration Act of 1992.

\section{0 - 1989 - state of emergency and the liberation struggle}

Militarisation was compounded during the 1980s, when the apartheid government declared a series of states of emergency and civilian ownership was galvanised by government propaganda that preyed on white fears. Hennie van Vuuren's exposé Apartheid, Guns and Money describes how Armscor (the state arms company that later became Denel) played a central role in an international criminal conspiracy to enable the state to buy guns and other weapons. ${ }^{[7]}$ These were also circulated to the security apparatus of the Bantustans, which maintained their own armed police and military forces. However, firearms were

Table 1. Firearm-related publications in the health science literature,
by decade - 1970 - 2019*
\begin{tabular}{lllll}
\hline Decade & Public health & Health systems & Nature of injury & All types \\
\hline $1970-1979$ & - & - & - & - \\
$1980-1989$ & 3 & 1 & 1 & 5 \\
$1990-1999$ & 10 & 3 & 19 & 32 \\
$2000-2009$ & 39 & 6 & 32 & 77 \\
$2010-2019$ & 36 & 7 & 43 & 86 \\
Total & 88 & 17 & 95 & 200 \\
*A complete listing of these articles by date of publication is available online at http://medat.samrc.ac.za/data/lit_sum/ \\
summary_of_literature.xlsx
\end{tabular}

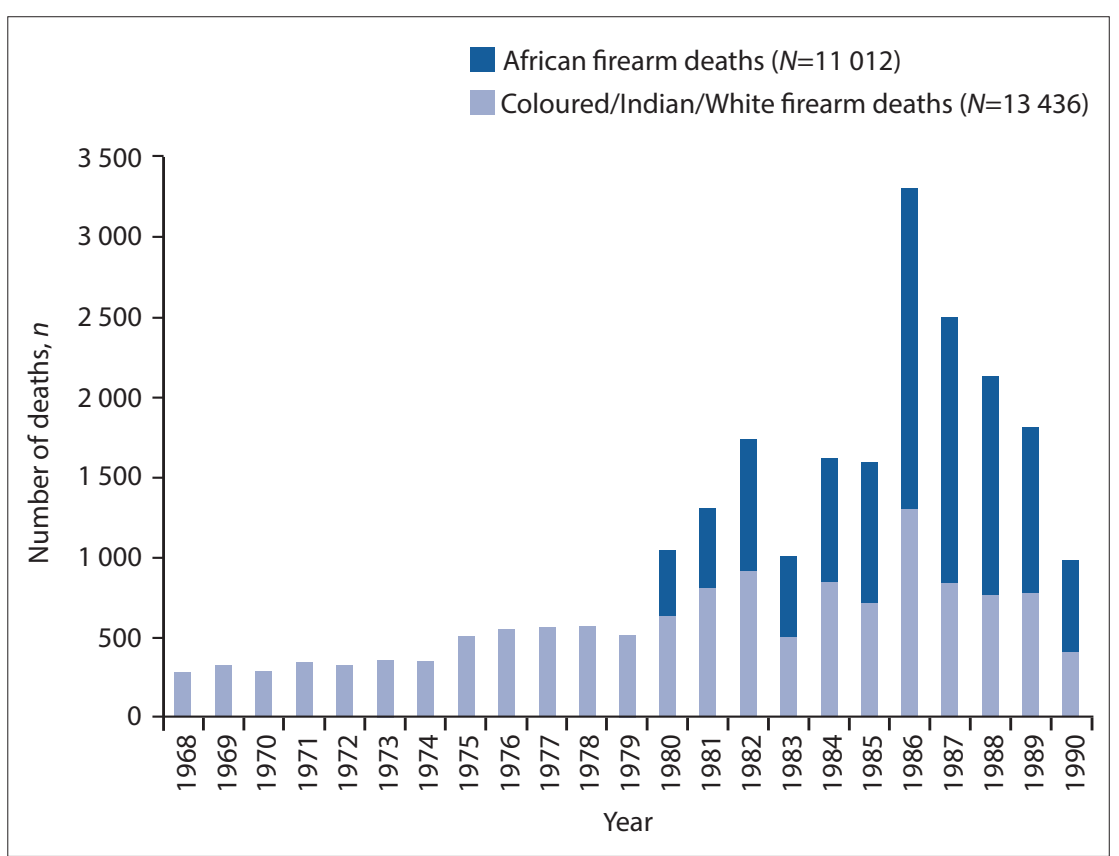

Fig. 1. Annual gunshot deaths for all causes (ICD9: E922, E955, E965, E970, E985) in South Africa, $1968-1990(\mathrm{~N}=24448)$. not only a means of suppression, but also potentially a means to resist white minority rule. The armed wings of both the ANC and PAC were involved in cross-border smuggling and stashing of secret arms caches.

Veller and Green's 1982 account of gunshot injuries at Johannesburg Hospital and their impact on workload and bed occupancy was the first firearm-related publication that we encountered in the SA health sciences literature. We identified a total of five firearm-related articles in the health sciences literature during this decade. A sign of the times was that three of these described injuries arising from civilian conflict with the state security apparatus. ${ }^{[8-10]}$ Perrot's 1989 article on the epidemiology of violence in Pietermaritzburg noted the high case-fatality rate for shootings, one-third of which ended fatally. ${ }^{[11]}$

In the late 1980s the SAMRC began to take an interest in injury research, with the establishment of the National Trauma Research Programme, which began to document and profile selected injury issues. Although firearm deaths did not feature at the onset, the SAMRC's formative surveillance efforts did eventually give rise to national fatal and non-fatal injury surveillance projects that would later highlight the important role of firearms. This trend was bolstered by simultaneous research in Johannesburg and Soweto on traumatic brain injury ${ }^{[12,13]}$ and hospital-treated non-fatal injuries. ${ }^{[14-16]}$

\section{0 - 1999 - democracy and disruption}

The apartheid era ended abruptly with the unbanning of the ANC, the release of Nelson Mandela, and the transition from an interim to a democratically elected government. This heralded a time of great excitement and anticipation, but also fear, disruption and violence. Many whites armed themselves in preparation for violent reprisals post democracy and the pool of civilian weapons was complemented by a flood of militaryissue weapons that circulated following the cessation of armed conflict and also the dismantling of the Bantustan security apparatus. Consequently, firearms became an important locus for control as they presented a possible escalation risk in the prevailing climate of violence.

There were several initiatives for consolidation during the first five years of democracy (1994 - 1998), including a national firearms amnesty and joint operations between SA and neighbouring states to disrupt the illegal arms trade. The National Crime Prevention Strategy 
identified firearm control as a priority, the AAA was amended to prohibit the lending of guns, and the Minister of Safety and Security appointed a committee to investigate a new firearm policy for legal firearms that would eventually develop into the FCA. The police were also more actively involved in seizing unlicensed firearms as part of a firearms strategy that included an audit of state firearms, and the piloting of firearm registration models.

During this decade, there was growing recognition of the burden of violence in SA and that firearms featured prominently as a major cause of injuries and fatalities. We counted a total of 32 publications, of which just 10 were public health-related. Injury research efforts began to investigate injury epidemiology in earnest as data from various sources were collated. In Cape Town, mortuaries identified 20\% more firearm-related deaths in children and adolescents than were included in official police crime statistics. ${ }^{[17]}$ MacDonald and Lerer ${ }^{[18]}$ explored the general pattern of weekly firearm and non-firearm homicides and suicides for the 6-year period from 1986 to 1991 and noted a distinct increase in firearm homicide in mid-1991.

At the SAMRC, a study conducted at Groote Schuur Hospital found that almost $42 \%$ of 969 patients presenting with firearm-related injuries required surgery, ${ }^{[19]}$ and an all-cause mortuary-based injury mortality surveillance pilot study that identified firearms as the second leading external cause of homicide, was a precursor to injury surveillance initiatives that would later monitor firearm homicide trends. ${ }^{[20]}$

\section{0 - 2009 - firearm control}

The start of this decade was a period of huge social and political change, with many new progressive laws promulgated. ${ }^{[21]}$ The Firearms Control Bill (B34 of 2000) was one of several with substantial input from the public and civil society and research organisations including the SAMRC, which partnered with the Council for Scientific and Industrial Research (CSIR) and the University of South Africa (UNISA) to develop a National Injury Mortality Surveillance System (NIMSS). Results of the NIMSS pilot study indicated that $45 \%$ of injury deaths were due to homicide, of which $51 \%$ involved firearms ${ }^{[22]}$ and early NIMSS outputs were incorporated into materials from the National Crime Prevention Centre's Firearm Programme advocating the enactment of the FCA. ${ }^{[23]}$

The Firearms Control Bill was presented and approved by parliament during the course of 2000 and, in April 2001, the President assented to the FCA (Act 69 of 2000) and signed it into law. As well as requiring training tests for licences and compulsory background checks, the FCA banned certain types of firearm, required additional licences and set limits on each gun owned, and increased age requirements for ownership. There were several immediate responses to the new legislation. The police received additional human and physical resources to implement the FCA and commenced extensive special operations to recover unregistered firearms, and citizens were encouraged to hand in unlicensed weapons. Stricter assessment of new firearm licence applications saw the refusal rate of civilian applications increase to $70 \%$ by April 2003. ${ }^{[5]}$

Research into firearms intensified during this decade, during which we counted 77 peer-reviewed publications. Half of these were public health-related, but most were forensic analyses of homicide and injury mortality trends, and firearms were seldom a primary focus. Several studies described analyses of postmortem records in the Transkei region, where there had been a dramatic increase in firearm homicides from 27 to 42 per 100000 between 1993 and $2004,{ }^{[24]}$ but the impact of firearm control legislation in reducing deaths was only evaluated in the next decade. In addition to the NIMSS reports, the SAMRC published several policy and research briefs that highlighted the role of firearms in violence against women. For example, a 2009 Policy Brief that presented a national rape prevention agenda noted the detrimental effect of gun culture linking manliness with guns. ${ }^{[25]}$ This spanned both legal and illegal ownership, with legal guns kept at home often being used by men against women partners, although it was noted that men who owned guns legally were not more likely to be perpetrators of rape. ${ }^{[26]}$

From a surgical training perspective, the increase in firearmrelated injuries provided training and surgical advancement. This was reflected in the increasing number of studies describing the nature of firearm-related injuries (32 over 10 years), which was not surprising, given the substantial burden that they imposed on the health system. The indirect and human-value costs of severe injuries may be higher than for fatal injuries, particularly if they occur more frequently and result in permanent disabilities. One study on the hospital and medical treatment costs of non-fatal firearm injuries in 2003 showed that the mean hospital cost per patient per day was more than 13 times the annual government per capita expenditure on health..$^{[27]}$

\section{0 - 2019 - the World Cup and nine wasted years}

SA firearm research has been most prolific over the last 10 years and spanned a wider range of topics and settings than in previous decades. Studies on the nature of firearm injuries increased to 43 , and of the 36 public health studies, 8 focused specifically on firearms. . $^{[5,628-33]}$

At the SAMRC, Abrahams et al's $\mathrm{s}^{[34]} 2010$ review of guns and gender-based violence drew on several SA studies including national homicide studies, intimate partner studies, studies with male participants and studies from the justice sector. They found that SA had the highest reported rate of females murdered by shooting globally among countries not at war, as well as strong associations between gun ownership and the deaths of female partners. The community-based sample of adult men showed that unlicensed gun ownership was more common among men who had ever raped than the equivalent figure of $6.2 \%$ among men who had not committed rape $(p<0.00) .{ }^{[26]}$

The SAMRC conducted the first nationally representative study of injury mortality in 2011. ${ }^{[2]}$ Urban areas had been overrepresented in surveillance data, and the availability of national data indicated that firearm homicide was 2.6 times higher in metro areas than in non-metro areas after adjusting for age, sex and race differences. Consequently, firearms can be considered one of the drivers of higher rates of homicide in metro areas. ${ }^{[35]}$

SAMRC researchers published 4 studies that showed the impact of the FCA in reducing firearm-related deaths and homicides in particular. First, a comparative analysis of 2 female homicide surveys conducted in 1999 and 2009 found that there were significantly fewer intimate and non-intimate female homicides in the second survey, which was attributed to stricter firearm control legislation. ${ }^{[4]}$ Second, in a study of more than 30000 homicides across 5 SA cities, a significant decrease in firearm homicides was observed relative to non-firearm homicides. ${ }^{[4]}$ The study was limited by the short 2001 - 2005 time period for which comprehensive citywide data were available, which was addressed by the third and fourth studies.

The third study reviewed death notification data from 1997 - 2013, which showed a marked decrease in firearm deaths. This period spanned the implementation of SA's FCA and associated gun control measures, after which firearm homicides decreased, as well as a subsequent period during which the FCA gains were eroded by a relaxation of the FCA's strict licensing conditions and a welldocumented instance of police corruption. This is particularly evident in Fig. 2, which draws on the SAMRC's ongoing collation of Stats SA death notification data to extend the period of observation 


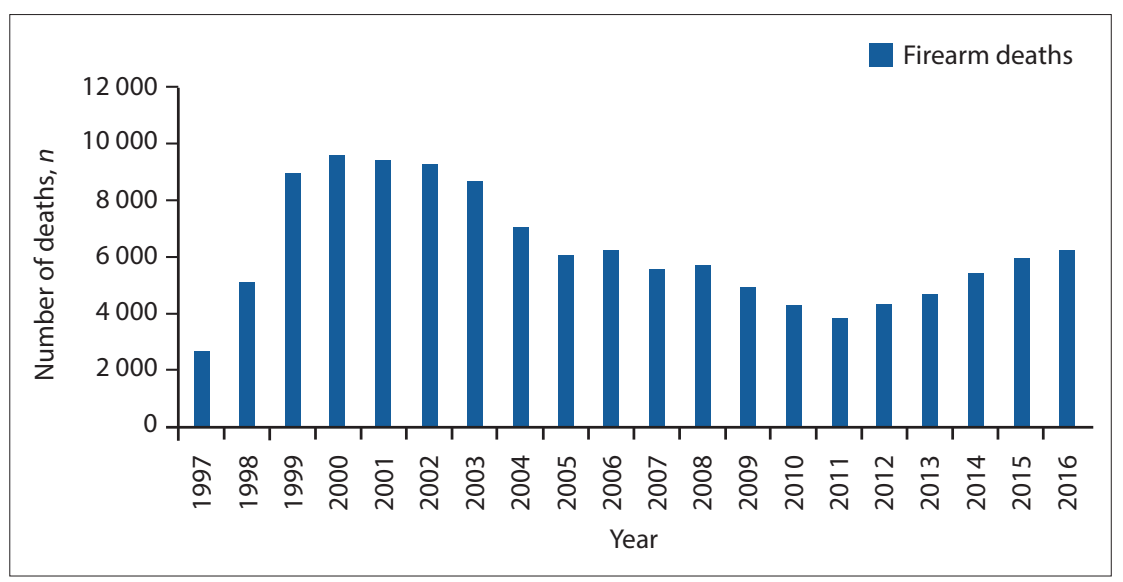

Fig. 2. Annual gunshot deaths for all causes (ICD10: W32 - W34, X72 - X74, X93 - X95, Y22 - Y24) in South Africa, 1997 - 2016 ( $(\mathrm{N}=123$ 820).

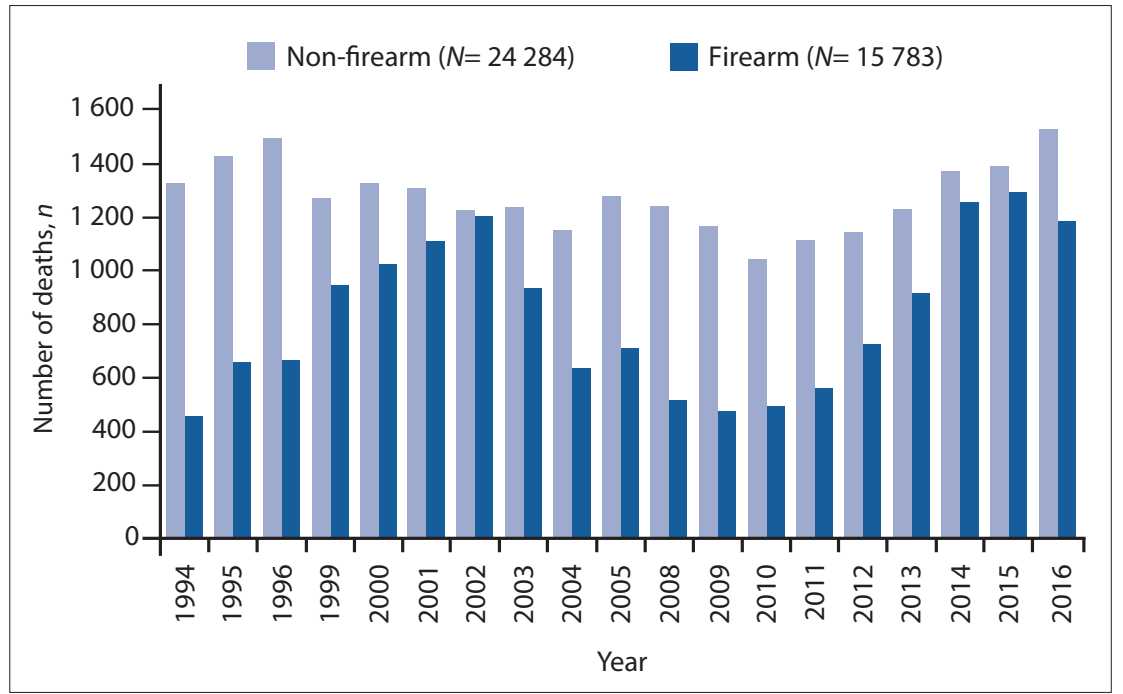

Fig. 3. Firearm and non-firearm homicide in Cape Town, $1994-2016 .^{*}$

${ }^{*}$ Data not available for 1997 - 1998 and 2006 - 2007.

Source: 1994 - 2013 data (Matzopoulos et al., ${ }^{[5]}$ 2018) 2014 - 2016 data (Evans et al., ${ }^{[36]} 2018$ ).

from 1997 to 2016. However, this data source was unable to distinguish the manner of death and hence disaggregate non-firearm homicides as a control group for firearm homicides. ${ }^{[32]}$

The fourth study addressed this shortcoming through an analysis of firearm and non-firearm homicides in Cape Town, over a 19-year period from 1994 to 2013. In Fig. 3, we reproduced and updated the firearm and non-firearm homicide trends from this study with recent data published by the provincial health department. ${ }^{[36]}$ It is clear that there is more variance in the firearm homicide trend than in the nonfirearm trend. There is also considerable similarity between the Cape Town firearm homicide trend (Fig. 3) and the national all cause firearm mortality trend (Fig. 1), with a peak circa 2000 - 2002, a decline to 2010 - 2011 and subsequent increase. Over and above the FCA effecting a decrease in firearm homicides from 2000, Matzopoulos et al. ${ }^{[5]}$ surmised that there were two key drivers for the subsequent increase in firearm homicides. Nationally, around the time of the 2010 World Cup, the Minister of Police suspended the head of the Central Firearms Registry as part of an internal review before instructing the police to clear the Central Firearm Registry backlog, which resulted in the expedited finalisation of more than 1 million firearm applications including licence renewals and new licences. ${ }^{[37,38]}$ In the Western Cape (WC), there was an additional lapse in firearm control when firearms marked for destruction were fraudulently issued to Cape Town criminals by corrupt police officials and gun dealerships. This resulted in more than 2400 firearms being sold to criminal syndicates between 2007 and $2014,{ }^{[39-43]}$ and might also account for the increase in firearm mortality becoming apparent earlier in the WC.

\section{Discussion}

The prevention of violence is complex and requires a sustained multi-dimensional approach across all levels of society. Most strategies require long-term investment before they deliver results (e.g. early childhood development, improving positive adult involvement or changing societal and cultural norms around violence). There is also emerging evidence internationally ${ }^{[44]}$ and in $\mathrm{SA}^{[45]}$ that efforts to improve the built environment in which people live and work can reduce interpersonal violence. However, there are relatively few strategies that will have a major societal impact in the short term. Restrictions on firearms, one of the few known risks for violence under the direct regulatory control of government, is one of the exceptions. ${ }^{[46]}$

The SA experience is not unique. A recent systematic review of 130 studies across 10 countries found that reductions in firearm deaths were associated with the simultaneous implementation of laws encompassing multiple firearm restrictions, and SA was mentioned as a key example alongside the USA, Canada, Australia, New Zealand (NZ) and Brazil. ${ }^{[47]}$ Several studies have shown significant decreases following access restrictions through including one study each from NZ, ${ }^{[48]}$ Brazil $^{[49]}$ Austria $^{[50]}$ and Colombia, ${ }^{[51]}$ and two from the USA. ${ }^{[52,53]}$

In Australia, studies have attributed the decline in firearm homicide and suicide to the 1996 National Firearms Agreement designed to prevent mass shootings. ${ }^{[54,55]}$ More recent analysis has shown that although the legislation may have been effective in reducing mass shootings, it had no statistically observable additional impact on suicide, possibly owing to the limited scope of the legislation. Instead the authors surmise that the decreases arose from an earlier federal government initiative that included more detailed and comprehensive gun control policy amendments in response to a series of firearm homicides in the late 1980s. ${ }^{[56]}$

The challenge for government is to apply their firearm control strictly and consistently while continuing to ensure long-term investment in strategies that will ultimately deliver a sustained reduction in violence. This was attempted in the WC with the adoption of a Policy Framework for Violence Prevention, but only had mixed success. ${ }^{[57]}$ However, the adoption of a policy founded on similar principles by the national government would provide the necessary policy coherence that would be required to make a meaningful difference. Such an approach is consistent with the Sustainable Development Goals, which recognise violence 
as a major developmental impediment and call for the prevention of violence against all citizens - the first time that men are included in the global violence prevention agenda. ${ }^{[58]}$ This is of particular importance in SA, which has one of the highest homicide rates in the world and where men account for $85 \%$ of homicide victims. ${ }^{[2]}$

Research into firearm legislation has been selected as one of two areas of priority research for violence prevention in a recent study by the Research Agenda Project Group of the World Health Organizationled Violence Prevention Alliance. ${ }^{[59]}$ It has been shown internationally that much of the variation between countries in national homicide rates can be explained by the extent of firearm homicide, as the total homicide rate in countries is closely associated with the rate of firearm homicides. ${ }^{[60]}$ Already we have seen the effects of such a strategy in the few decades since democracy.

\section{Emerging priorities and new avenues for research}

Unfortunately, the necessary data to identify groups at risk, allocate resources and monitor interventions are not available from current sources of routine data, whether from vital registration ${ }^{[32,61]}$ or the police. ${ }^{[2,62]}$ There is a real need to invest in the collection of reliable data to drive our prevention efforts and to consolidate mortality and morbidity data to provide a fuller understanding of the epidemiology of firearm injury.

More routine data need to be collected. For example, the most recent disaggregated police statistics show that firearms were used in $41.3 \%$ of murders in the 2017/2018 reporting period - the most frequently used murder weapon. ${ }^{[63]}$ This increase in murder immediately suggests an increase in the level of violence in society, but this may not necessarily be true. Firearms result in more severe and fatal injuries than other weapons used in interpersonal conflict. It is conceivable that increased lethality owing to firearm use has pushed up murder rates, whereas levels of violence have remained similar. Consequently, we argue that SA has not seen a reduction in violence, but rather that the fluctuating homicide rates are influenced by the country's adherence to firearm control policy.

If such data were provided on an annual basis it would be easier to recognise the influence of firearm control policies and there would be additional impetus to strengthen restrictions. It is estimated that there are $\sim 3$ million registered (legal) firearms, ${ }^{[64]}$ which equates to at least 5 civilian firearms per every 100 persons in SA. The number of illegally held firearms remains unknown. Given the high rates of violence and the demonstrated benefits of effective firearm control, it is incomprehensible that these issues do not feature prominently or clearly in the manifestos of most political parties that competed in the latest elections.

Over and above that, there needs to be a concerted effort to report and collect more information on non-fatal events. The severity profile is particularly important, given the higher risk of fatalities and severe injuries from gunshot wounds compared with other causes. There is a need to develop cost estimates for the additional burden of care and associated costs arising from these injuries, as they will need to be budgeted for, with the forthcoming national health insurance. This necessity should provide additional stimulus to prevention agenda, as the full costs should either prompt a more restrictive policy response or a regulatory mechanism to amortise the associated costs.

Acknowledgements. We are grateful to Natasha Langdown of the SAMRC's Knowledge and Information Management Services, who assisted in searching and locating some of the literature that we drew on in this review, and to Ria Laubscher of the SAMRC's Biostatistics Unit, who maintains the Death Registration data and assisted in extracting the relevant statistics for Figs 1 and 2.
Author contributions. RM conceived and designed the study; RM, MP, $\mathrm{DB}$ and NA contributed to the writing of the manuscript; RM, MP, DB and NA agreed with the manuscript results and conclusions; RM, MP, DB and NA: ICMJE criteria for authorship read and met.

Funding. RM, MP, DB and NA are funded by the SAMRC.

Conflicts of interest. RM serves on the board of Gun Free South Africa, but receives no remuneration for his service to the organisation.

1. Wang H, Naghavi M, Allen C, et al. Global, regional, and national life expectancy, all-caus mortality, and cause-specific mortality for 249 causes of death, 1980-2015: A systematic analysi for the Global Burden of Disease Study 2015. Lancet 2016;388(10053):1459-1544.

2. Matzopoulos R, Prinsloo M, Pillay-van Wyk V, et al. Injury-related mortality in South Africa: A retrospective descriptive study of postmortem investigations. Bull World Health Organ 2015;93(5):303-313

3. Pillay-van Wyk V, Msemburi W, Laubscher R, et al. Mortality trends and differentials in South Africa from 1997 to 2012: Second National Burden of Disease Study. Lancet Glob Heal 2016;4(9).

Abrahams N, Mathews S, Martin LJ, Lombard C, Jewkes R. Intimate partner femicide in South Africa in 1999 and 2009. PLoS Med 2013;10(4):e1001412.

Africa in 1999 and 2009. PLoS Med 2013;10(4):el 1001412.
5. Matzopoulos R, Simonetti J, Prinsloo M, et al. A retrospective time trend study of firearm and nonMatzopoulos R, Simonetti J, Prinsloo M, et al. A retrospective time trend study of
firearm homicide in Cape Town from 1994 to 2013. S Afr Med J 2018;108(3):197.

firearm homicide in Cape Town from 1994 to 2013. S Afr Med J 2018;108(3):197.
6. Matzopoulos RG, Thompson ML, Myers JE. Firearm and nonfirearm homicide in 5 South African Matzopoulos RG, Thompson ML, Myers JE. Firearm and nonfirearm homicide in 5 South
cities: A retrospective population-based study. Am J Public Health 2014;104(3):455-460.

7. Van Vuuren H. Apartheid, Guns And Money: A Tale Of Profit. London: Hurst Publishers; 2018

8. Knobel GJ. Effect of civil unrest on the incidence of violent and non-natural deaths. S Afr Med I 1986;70(2):83-88

9. Duflou JA. A study of 93 deaths from gunshot injuries during security force action in the Greater Cape Town area, 1985. S Afr Med J 1986;70(2):88-90.

10. Cohen MA. Plastic bullet injuries of the face and jaws. S Afr Med J 1985;68(12):849-852.

11. Perrott CAV. Pietermaritzburg: A city of violence. J Emerg Med 1989;7(5):485-459.

12. Brown DSO, Nell V. Epidemiology of traumatic brain injury in Johannesburg - I. Methodological issues in a developing country context. Soc Sci Med 1991;33(3):283-287.

13. Nell V, Brown DSO. Epidemiology of traumatic brain injury in Johannesburg - II. Morbidity Nell V, Brown DSO. Epidemiology of traumatic brain
mortality and etiology. Soc Sci Med 1991;33(3):289-296.

mortality and etiology. Soc Sci Med 1991;33(3):289-296.
14. Butchart A, Brown DSO. Non-fatal injuries due to interpersonal violence in Johannesburg -

Butchart A, Brown DSO. Non-fatal injuries due to interpersonal violence in Johan
Soweto: Incidence, determinants and consequences. Forensic Sci Int 1991;52(1):35-51.

Soweto: Incidence, determinants and consequences. Forensic Sci Int 1991;52(1):35-51.
15. Butchart A, Nell V, Yach D, Johnson K, Radebe B. Epidemiology of non-fatal injuries due to external causes in Johannesburg-Soweto. Part I. Methodology and materials. S Afr Med J 1991;79(8):466-471. 6. Butchart A, Nell V, Yach D, et al. Epidemiology of non-fatal injuries due to external causes in Johannesburg-Soweto. Part II. Incidence and determinants. S Afr Med J 1991;79(8):472-479.

17. Wigton A. Firearm-related injuries and deaths among children and adolescents in Cape Town 1992-1996. S Afr Med J 1999;89(4):407-410.

8. MacDonald IL, Lerer LB. A time-series analysis of trends in firearm-related homicide and suicide. Int J Epidemiol 1994;23(1):66-72.

19. Peden M, Van der Spuy J. The cost of treating firearm victims. Trauma Rev 1998;6:4-5.

20. Lerer LB, Matzopoulos RG, Phillips R. Violence and injury mortality in the Cape Town metropole. S Afr Med J 1997;87(3):298-301.

21. Report of the High Level Panel on the assessment of key legislation and the acceleration of Report of the High Level Panel on the assessment of key legislation and the acceleration of
fundamental change. 2017. https://www.parliament.gov.za/storage/app/media/Pages/2017/ fundamental change. 2017. https://wWW.parliament.gov.Za/storage/app/media/
october/High_Level_Panel/HLP_Report/HLP_report.pdf (accessed 5 August 2019).

22. Butchart A, Peden M, Matzopoulos R, et al. The South African National Non-Natural Mortality Surveillance System - rationale, pilot results and evaluation. S Afr Med J 2001;91(5):408-417

23. Chetty R (ed). Firearm Use and Distribution in South Africa. Pretoria: The National Crime Prevention Centre, 2000

24. Meel BL. Firearm fatalities in the Transkei region of South Africa, 1993-2004. S Afr Med J 2005;95(12):963-967.

25. Jewkes R, Abrahams N, Mathews S, et al. Preventing rape and violence in South Africa: Call for leadership in a new agenda for action. Pretoria: MRC, 2009. Available from: http://www.mrc. ac.za/policy-briefs/preventing-rape-and-violence-south-africa-call-leadership-new-agenda-action (accessed 5 August 2019).

26. Jewkes R, Sikweyiya Y, Morrell R, Dunkle K. Understanding men's health and use of violence: Interface of rape and HIV in South Africa. Cape Town: MRC, 2009. Available from: http://www. Interface of rape and HIV in South Africa. Cape Town: MRC, 2009. Available from: http://www.
mrc.ac.za/policy-briefs/understanding-mens-health-and-use-violence-interface-rape-and-hivmrc.ac.za/policy-briefs/understanding
south-africa (accessed 5 August 2019).

27. Allard D, Burch VC. The cost of treating serious abdominal firearm-related injuries in South Africa. Allard D, Burch VC. The cost of trati
S Afr Med J 2005;95(8):591-594.

28. Abrahams N, Jewkes R, Mathews S. Guns and gender-based violence in South Africa. S Afr Med J 2010;100(9):586-588.

29. Naidoo $\mathrm{S}$, Van As AB. Vulnerability of children to gunshot trauma in violence-prone environment: The case of South Africa. Afr J Paediatr Surg 2011;8(1):101

30. Campbell NM, Colville JG, Van der Heyde Y, Van As AB. Firearm injuries to children in Cape Town, South Africa: Impact of the 2004 Firearms Control Act. S Afr J Surg 2013;51(3):92.

31. Matzopoulos R. Gun control saves lives. S Afr Med J 2016;106(6):544.

32. Matzopoulos R, Groenewald P, Abrahams N, Bradshaw D. Where have all the gun deaths gone? S Afr Med J 2016;106(6):589.

33. Meel B. Twenty-three-year trend in firearm deaths in the Transkei subregion of South Africa (19932015). Med Sci Law 2018;58(2):102-108
.

34. Abrahams N, Jewkes R, Mathews S. Guns and gender-based violence in South Africa. S Afr Med J 2010;100(9):586-588.

35. Prinsloo M. Estimating injury mortality in South Africa and identifying urban-rural differences. Cape Town: Open UCT, 2019.

36. Evans J, Morden E, Zinyakatira N, et al. Western Cape Injury Mortality Profile: 2010-2016. 2018 https://www.westerncape.gov.za/assets/departments/health/mortality_profile_2016.pdf (accessed 5 August 2019).

37. South African Police Service. Crime report 2010/2011: SAPS together squeezing crime to zero: SAPS members, my family - together pushing back the frontiers of evil. Pretoria: SAPS, 2011.

38. South African Police Service. Annual Report 2011/2012. Pretoria: SAPS, 2012.

39. Serrao A. Cop, guns linked to gangsters. Star, 23 March 2015. http://www.iol.co.za/news/crimecourts/cop-guns-linked-to-gangsters-1.1835604 (accessed 5 August 2019).

40. Dolley C. Police 'gave guns to gangs'. Weekend Argus, 28 September 2014. http://www.iol.co.za/ news/crime-courts/police-gave-guns-to-gangs-1.1756940 (accessed 5 August 2019). 
41. Baadjies M. 'Dirty cop sold us 200 guns'. Daily Voice. 15 July 2015. https://www.iol.co.za/news/dirty-copsold-us-200-guns-1885760 (Accessed 5 August 2019).

42. Petersen T. Ex-cop gets 18 yaars for stealing, reselling guns to Cape gangsters. News24.com2016;23-25 http://www.news24.com/SouthAfrica/News/ex-cop-gets-18-years-for-stealing-reselling-guns-to-capegangsters-20160621 (accessed 5 August 2019).

43. Thamm M. When Hell is not hot enough : A top cop who supplied weapons to country's gangsters and right wingers. Daily Maverick. 4 July 2016. http://www.dailymaverick.co.za/article/2016-07-04-whenright wingers. Daily Maverick. 4 July 2016. http://www.dailymaverick.co.za/article/2016-07-04-when-
hell-is-not-hot-enough-a-top-cop-who-supplied-weapons-to-countrys-gangsters-and-right-wingers/\#. hell-is-not-hot-enough-a-top-cop-wh

44. Cassidy T, Inglis G, Wiysonge C, Matzopoulos R. A systematic review of the effects of poverty deconcentration and urban upgrading on youth violence. Health Place 2014;26:78-87.

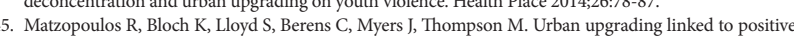
. Macopolos R, Bin social outcomes in Cape Town, South Anca. In. Salahub J, Goltsacher M, De Boer J, Zaaroura M, UK: Routledge, 2019:69-89.

46. Matzopoulos R, Bowman B, Mathews S, Myers J. Applying upstream interventions for interpersonal violence prevention: An uphill struggle in low- to middle-income contexts. Health Policy (New York) violence preventio:
2010;97(1):62-70.

47. Santaella-Tenorio I, Cerdá M, Villaveces A, Galea S. What do we know about the association between firearm legislation and firearm-related injuries? Epidemiol Rev 2016;38(1):140-157. https://doi. firearm legislation and firen

48. Beautrais AL, Fergusson DM, Horwood LJ. Firearms legislation and reductions in firearm-related suicide deaths in New Zealand. Aust NZ J Psychiatry 2006;40(3):253-259.

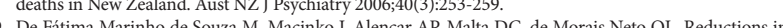
. firearm-rlated mote Kapusta ND, Etzersdofer E, Krall C, Sonneck G. Firearm legislation reform in the European 2007:191(3):253-257.

51. Villaveces A, Cummings P, Espitia VE, Koepsell TD, McKnight B, Kellermann AL. Effect of a ban on ties. JAMA 2000;283(9):120

52. Hepburn L, Azrael D, Miller M, Hemenway D. The effect of child access prevention laws on unintentional child firearm fatalities, 1979-2000. J Trauma 2006;61(2):423-428.
53. Webster DW, Vernick JS, Zeoli AM, Manganello JA. Association between youth-focused firearm laws and youth suicides. JAMA 2004;292(5):594-601.

54. Chapman S, Alpers P, Agho K, Jones M, Chapman PS. Australias 1996 gun law reforms: Faster falls in firearm deaths, firearm suicides, and a decade without mass shootings. Inj Prev 2006;12(6):365-372.

55. Ozanne-Smith J, Ashby K, Newstead S, Stathakis VZ, Clapperton A. Firearm related deaths: The impact of regulatory reform. Inj Prev 2004;10(5):280-286

56. Gilmour S, Wattanakamolkul K, Sugai MK. The effect of the Australian National Firearms Agreement on suicide and homicide mortality, 1978-2015. Am J Public Health 2018;el-e6.

57. Matzopoulos R, Myers JE. The Western Cape Government's new Integrated Provincial Violence Prevention Policy Framework: Successes and challenges. Agrress Violent Behav 2014:19(6):649-654.

8. Matzopoulos R, Bowman B. Sustainable development goals put violence prevention on the map. J Public Health Policy 2016:37(2):260-262

59. Mikton CR, Tanaka M, Tomlinson M, et al. Global research priorities for interpersonal violence prevention: A modified Delphi study. Bull World Health Organ 2017;95(1):36-48.

60. Bhalla K, Matzopoulos R, Harrison J, Knowlton L, Gilgen E, Alvazzi del Frate A. Tracking national homicide rates: generating estimates using vital registration data. Small Arms Surv Issue Br 2012;(1):1-12

61. Prinsloo M, Bradshaw D, Joubert J, Matzopoulos R, Groenewald P. South Africa's vital statistics are currently not suitable for monitoring progress towards injury and violence Sustainable Development Goals. S Afr Med J 2017:107(6):470.

62. Prinsloo M, Matzopoulos R, Laubscher R, Myers J, Bradshaw D. Validating homicide rates in the Western Cape Province, South Africa: Findings from the 2009 Injury Mortality Survey. S Afr Med J 2016;106(2):193-195

63. South African Police Service. On a journey to a safer South Africa crime situation in RSA twelve months 01 April 2017 to 31 March 2018. 2018;(March):1-184. https://www.saps.gov.za/services/long_version_ presentation_april_to_march_2017_2018.pdf (accessed 5 August 2019).

64. Alpers P, Rossetti A, Wilson M. Guns in South Africa: Number of registered firearms. Sydney School of Public Health, Univ Sydney. 2017. http://www.gunpolicy.org/firearms/compareyears/166/number_of registered_firearms (accessed 5 August 2019). 